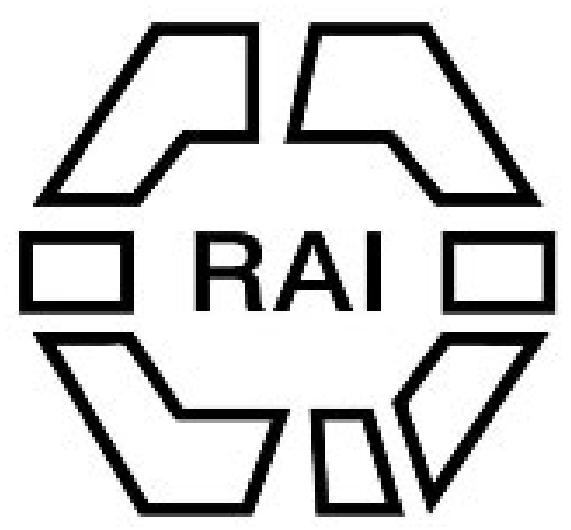

Remarks on Totemism, with Especial Reference to Some Modern Theories Respecting It Author(s): Edward B. Tylor

Source: The Tournal of the Anthropological Institute of Great Britain and Ireland, Vol. 28, No. $1 / 2$ (1899), pp. 138-148

Published by: Royal Anthropological Institute of Great Britain and Ireland

Stable URL: http://www.jstor.org/stable/2842940

Accessed: 31/07/2013 01:26

Your use of the JSTOR archive indicates your acceptance of the Terms \& Conditions of Use, available at http://www.jstor.org/page/info/about/policies/terms.jsp

JSTOR is a not-for-profit service that helps scholars, researchers, and students discover, use, and build upon a wide range of content in a trusted digital archive. We use information technology and tools to increase productivity and facilitate new forms of scholarship. For more information about JSTOR, please contact support@jstor.org. 


\title{
REMARKS ON TOTEMISM, WITH ESPECIAL REFERENCE TO SOME MODERN THEORIES RESPECTING IT.
}

\author{
By EuWakd B. Tylon, D.C.L., F.R.S., Professor of Anthropology in the \\ University of Oxford.
}

IT is desirable that I should state the purpose of my offering these remarks on Totemisn. Though I have written very little about it, ny first lines date as far back as 1867 , and a little later I came to be well acquainted with J. F. McLennan, the beginner of the systematic study of this and kindred branches of anthropology. At that time he was engaged on his papers on Worship of Animals and Plants, and we had much conversation on the philosophy of totems. The cause of my holding aloof from published discussions of the subject since has been a sense of its really bewildering complexity, coupled with the expectation that further research among the races of the lower culture would clear its outlines, as indeed has been to some extent the case, especially in North America and Australia, the regions where totemism proper is most at home. The particular cause of ny drawing up the present paper was my being invited to address a philosophical society meeting in Oxford under the presidency of Professor Sanday, the subject assigned to me being certain views on the anthropology of religion contained in the works of Mr. J. G. Frazer and Dr. F. B. Jevons. Whatever my hearers may have learnt from my remarks, at any rate I became aware that the time had come for a closer examination than seems to have been hitherto made as to the somewhat various and vague ideas which have become associated with the term totemism. It was evident that till this was done, it would not even be possible to ascertain what place the totem nay properly claim to occupy in the theory of religion. My having undertaken to describe the great TotemPost at Fox Warren, made the present a suitable occasion for bringing the general principles which this monument illustrates under the consideration of the Anthropological Institute. It will be needful for me to dissent from somc current views and, what is of more consequence than such critical objections, to draw attention to the confusion in terms and definitions in use, which interferes with distinct reasoning. May I say that as time prevents any attempt at fully arguing out the problems raised, all I positively undertake at present, is to bring forward evidence showing that particular conclusions are not really settled, and cannot be without further discussion.

When McLennan in 1865 published his Prinitive Marriage, his interest in Lotems was merely ilicidental to his study of exogamy. The North American 
totem animal only comes in as furnishing the family name which ciassitied clanship within whose limits marriage is forbidden, and though Sir George Grey had previously called attention to the close similarity between the kobong-clans of West Australia and the totem-clans of North America, Mclennan in referrings to him only attends to the question of intermarriage. It was in 1869 that the conception of totemism took shape in McLennan's mind as a great principle, one may even say the great principle of early religion, as well as early society. As his articles on the "Worship of Animals and Plants" in the Fortuightly Revicw in 1869-70 furnish the outsets of most of the lines along which the theory of tutemism has been carried on to this day, as well as of some of its turns which have obstructed progress, a brief indication must be given of the tenour of these remarkable papers.

McLennan begins: "The suljects of the inquiry are totems and totem-gods, or, speaking generally, animal and vegetable gods." The order of the expositiun, he continues, is to explain what totems are, and what are their usual concomitants; to throw light on the intellectual condition of men in the totem stage of development: to examine the evidence that mankind in prehistoric times came through the totem stage, having animals and plants, and the heavenly bodies conceived as animals for gods before the anthropomorphic gods appeared; and to reach the conclusion that the hypothesis of the ancient nations having come through the totem stage is sound. Now McLennan was quite aware of what goes to make a totem in North America, that it involves the division of tribes into totem-clans each with its proper totem-animal, and the rule of exogamy forbidding marriage within the clan so as to necessitate intermarriage between clans; the totem-animals being alsu regarded as kinsfolk and protectors of the clansmen, who respect them and abstain from lilling or eating them. Such totems, he remarks, prevail aunong two distinct groups of tribes, the American Indians and the aborigines of Australia, and it may he believed that many more instances of their prevalence will be brought to light. I mention this to show that he started with a distinct idea of what may be called totemism proper, with its division of tribes into clans allied to species of animals, ete., between whom and the men there were rules of marriage, protection, and respect. It will now be seen how, starting from this totemism proper, McLemuan proceeded to take in with it other kinds of animal and plant worship, and to form the result into an expanded doctrine which he continued to call totemism.

In order to understand McLennan's argument, its starting point has to be found in a narrative by J. Long, a trader and interpreter among the North American Indians in the last century. Of the Clippeways (Ojibwas), long writes, that one part of the religious superstition of the savages consists in cach of them having his totum, or favourite spiril, which he believes watches over him. This totam they conceive asstmes the shape of some beast or other, and therefore they never kill, hunt, or cuat the animal whose form they think this tutam bears. 
One of the Indians, whose totam was a bear, dreamt (it seems) that he went to a piece of swampy ground about five days' march from Long's wigwam, and saw a large herd of elks, moose and other animals. He went accordingly, and secing the animals he had dreamed of, fired and killed a bear. Shocked at the transaction, and lreading the displeasure of the Master of Life, whom he conceived he had highly offended, he fell down and lay senseless for some time; recovering from his state of insensibility he got up and was making the best of his way to Iong's housc when he was met in the road by another large bear, who pulled him down and scratched his face. The Indian relating this event, at his return, added in the simplicity of his nature that the bear asked him what could induce him to kill his totam, to which he replied that he did not know he was among the animals when he fired at the herd, that he was very sorry for the misfortume and hoped he would have pity on him; and that the bear then suffered him to depart, telling him to be more cautious in future, and to acquaint all the Indians with the circumstance, that their totams might be safe and the Master of Iife not angry with them. As he entered my house, Long continues, he looked at me very earnestly and pronounced these words: "Amik hunjey tı Kitchee Annascartiosey nind O Totam cawwicka nee wee geossay sannegat debwoye, or "Beaver! (Long's Indian name) my faith is lost, my totam is angry, I shall never be able to hunt any more."1

McLennan's comment on this story is as follows: "Should one be surprised to find that admonitory bear of the man's imagination worshipped as a god further on in the history of Bear tribes advancing undisturbed by external influences, correlated with the Master of Life in the Olympus, or even preferred to, or identified with him ?" On examination, however, I venture to think that neither can the traderinterpreter's account be accepted as correct, nor taken as a foundation for the hypothesis of the development of totem-animals into great deities which the anthropologist builds upon it. Long evidently mixed up two articles of Ojibwa belief which are quite distinct. He knew the word totem (ot-ote-m=lis ote, clanname or clan-animal) and indeed his book very likely introduced the word into European language; also he knew of the rule against killing or eating the totemanimal. But his book shows no sign of his having learnt the system of the Ojibwa clan, without which knowledge he would not understand how the totem-species of animal was common to the clan as a whole. 'When he describes it as a favourite spirit which watches over each Indian, he evidently confuses it with the guardian spirit in animal form, which the individual Ojibwa also had, and called not his totem but his manitu or spirit, in trapper's jargon his medicine. Then, as to the particular story in question, how does it prove that the imaginary bear, who, as the Indian declared, scratched his face and gave him a warning from the Master of Life, was a being in course of development intu a god to rival or become the Master of Life himself? It has to be noted as to these Ojibwas, that far from

1 J. Long, Foygages and travels of an Indiun Interpieter und Trader. London, 1791. 
their religion "alvancing undisturbed by external influences," it had really superposed on the old native beliefs the Jesuit missionary teaching, especially as to this Master of Life, who was so distinctly the Christian Deity that, as Long more than nnce mentions, the Indian name for a Roman Catholic priest was Mrster of Lifc's man. Not only do we find a development hypothesis of deities read into a story which does not contain it, but the whole account is a warning of the risk of uncontrolled theory as to divine evolution. From an angry bear in the backwoods to a supreme deity of the world is too long a course to be mapped out in merely ideal stages.

In following out McLennan's original and suggestive if inconclusive attempt to interpret the great gods of the world as evolved from the humbler rank of totemanimals, it has to be noticerl how other evidence of animal-worship had to be dealt with in orler to people the Totem Olympus with totem-gods of superior tribes. In order to make a place for the Natchez Indians of Florida, who claimed to be lescended from the sun, and were called suns accordingly, and took wives only from other clans, the funclamental idea of a totem-creature as one of a species is dropped without scruple, and these people are incorporaterl as totemists whose totem was the sun. Another great province of religion is annexed by a theory that gods who have their incarnations or embodiments in species of sacred animals may be considered as deities evolved from these animals as totems. For examples, the lighest Fijian deity is Ndengei, whose shrine is the serpent, and second to him is Tui Lakemba, who claims the hawk as his shrine, this claim being indeed disputed by another god who claims the hawk for himself. One god is supposed to inhabit the eel, wherefore the worshipper of the eel-god must never eat eels. The sacred animal receives food and reverence in the name of his god; when a lani-crab comes to the island of Tiliva, where he is sacred, but now seldom seen, presents are marle to him lest his gorl should loring drought or death on the islanders. On these. statements, derived from the Fiji and the Fijians of Thomas Williams, Melemman cormments thus:- "These gods are tribal, and no one can cloubt lut they are totems who have marle such progress as we above suggested the Bear might. make, and are become the objects of a more or less regular worship-the Serpent tribe dominant, and the Hawk trilse in the second place." Yet considering that there is no evidence of totems or totem-clans proper in Fiji, this conjecture which " no one can doubt" is one which no one need believe. Indeed, if it is assumed that every sacred animal is a totem and every group of worshippers a totemclan, this is to contrarlict McLennan himself, who in a passage close by defines totemism as fetishism plus exogany and materual descent, a definition which is in great measure throwing up his case. Such want of consistency shows that the whole Fortnightly Revicu essay is rather to be treated as an introuluctory speculation than as a system. It should be remembered that its author thought well to insert a note to the effect that he only submitted an hypothesis which even if it failerl would be useful in dealing with the evidence. What is still more to the purpose is that he never reprinted these articles, though he spent 
much time in his later years in gathering further materials bearing on the question. Necessary as they are to every student of the subject, it is satisfactory that they are now published in the supplementary volume of his works. ${ }^{1}$ But it would not be needful to criticise their details so many years after date, were it not that McLennan's authority has had weight enough to induce modern writers to repeat even his conjectures as established principles.

Mr. J. G. Frazer's little manual of Totemism ${ }^{2}$ is as a classified collection of evidence of permanent value to Anthropology. The writer treats totems under three heads, the clan-totem, common to a whole clan; the sex-totem, an Australian variety ; and the individual-totem, belonging to a single person and not hereditary. But the clan-totem being the most important, he explains that when totems and totemism are mentioned without qualification, the clan-totem is always referred to. Now it has been just mentioned how McLennan, when writing on animals, etc., in which Fijian gods become incarnate, treats these as equivalent to totems, with which in fact they have but a partial and doubtful analogy. Mr. Frazer not only follows this line of reasoning, but carries it further. His chief authority is Dr. Turner's Samoc. ${ }^{3}$ This book is familiar to me (in fact I wrote the preface to it), so that I was puzzled to read passages eited from it by Mr. Frazer, as to totems and clans connected with them, such being as foreign to Samoan as to Fijian institutions. Thus it is stated that the Samoans thought it deatl to injure or eat their totems, for the totem would take up his abode in the sinner's body till it caused his death; if a Turtle man ate of a turtle, he grew very ill and the voice of the turtle was heard in his inside, saying, "lhe ate me, I am killing him." It is related as from Dr. Turuer, that when among the cuttle-fish clan an offence of this kind had been committed, the clan met and chose a person to go through the pretence of being baked as an expiation. But on reference to the original passages in Dr. Turner's book, it will be found that neither totems nor totem-clans are there, either by name or description. It was a family god who said from within the body of the offending turtleeater, "I am killing this man, he ate my incarnation." As to the cuttle-fish, it was as a household god, that is, a god selected for one or more members of a family at their birth, that he was appeased by the ceremony of a human victim being baked in a cold oven. From these and other cases it appears that Mr. Frazer had so framed his mind on McLennan's theory, as to feel justified in altering the very terms of the account of Samoan religion, in order to make them fit with it. Yet Dr. Turner is an authority of the first class, and his understanding of the Samoan theology is confirmed by the Samoan Texts of Dr. Stiibel. ${ }^{*}$ The doctrine of totem-animals and the doctrine of incarnation-animals no doubt both belong to the general theory of animal worship, but it does not follow

1 J. F. McLennan, Stulies in Ancient History. Second Series, Appendix, 1896.

?.J. G. Frazer, Totemism, $1887 . \quad$ 'G. Turner, Scimou, 1881.

+ O. Stuebel, Samoanische Texte, Veröffentlichungen aus dem K. Museum fiir Vülkerkunde, Berlin, 1895. 
that a species of animals allied to a clan of men is to be regarded as the same as a species of animals inhabited by a god. Yet the theory of development of gods from totems has its chief support in the Fijian and Samoan gods, who, it is taken for granted, were thus invented out of their own sacred animals.

Let us test the value of such an assumption by the example of the great Malayo-Polynesian heaven-god Tangaloa, known from the Indian Archipelago down to New Zealand, and of whom the widespread myth is told of his creating the earth with the aid of his daughter, Turi the snipe. In Samoa he is called Tangaloa langi or Tangaloa of the Sky, and he becomes incarnate in the snipe as his sacred creature. Therefore, according to the totem-theory we are now discussing, this Polynesian Jupiter, as he has been called, may be set down as a highly developed snipe. Indeed, the theory has no limit in a religion in which any priest of authority need only give out that his god will appear in a rat or an eel, for rats or eels to be established as his incarnations, and claimed by European theorists as totems from which the god himself arose in days of old.

In arguing against premature conjectures as to the origin of deities, I am anxious that the investigation of causes tending in this direction should not be restricted. The development of ideas of deity in early religion is but imperfectly understood, and so far as known seems to have resulted from various and complex causes. Among such it is necessary to consider the tendency of mankind to classify out the universe, supposing each class of objects or actions to be under the headship of a mythical being of suitable rank, its ancestor, creator, maintainer, ruler. Far from being prejudiced against this process of formation of gods, I did my best many years ago to collect a set of examples of such generalisation. ${ }^{1}$ Thus among the American Indians, each kind of animals was believed to have an Elder Brother, as it were the principle and origin of all the individuals, and so marvellously great and powerful, that as the missionary who mentions them declares, the elder brother of the beaver is as big as our cabin. Again, in Slavonic folklore, we hear of the snake older than all snakes, and the raven elder brother of all ravens, etc. These with others, such as the Peruvian stararchetypes of tigers, sheep, etc., I classed under the heading of "species-deities." Mr. Frazer naturally seeks support for the theory of totem-gods in these cases, and to the two which appear in his manual he adds a statement from Falkner's Description of Patagonic, written in the last century, which it is best to set down here more fully. The Jesuit missionary mentions the deities living in subterranean caverns, each of whom presides over one particular cast or family of which he is supposed to have becn the creator. Some make themselves of the cast of the tiger, some of the lion, some of the guanaco, and others of the ostrich, etc. When an Indian dies, his soul goes to live with the deity who presides over his particular family. They believe that their good deities made 
the world, that they first created the Indians in their cares, and when the beasts, birds, and lesser animals were created, those of the more nimble kind came immediately out, etc., etc. But taking Father Falkner's account as it stands (and indeed according to Captain Musters, the gods are still there in the caves), it seems in no way to imply that the divine creators of the world, the men, and the animals, were themselves animal-gods. As, however, a species of totem-animals is a class, it is always open to possibility that it may be thought to have a class-deity over it. If such a totem-deity can satisfactorily be traced, let him by all means be acknowledged and receive such spiritual rank as he is entitled to. As yet I have met with no valid instance of such divine development taking place. The nearest approach to such I can offer is arnong the Haidas of North-West America, who have two phratries or groups of totem-clans, called, from their principal totems, the Raven and the Wolf or Eagle. Also the Haidas tell stories of two great personages, Yêtl and his rival Kanuk, who figure in legends of creation of the earth, the getting of fire, and the like. Now Yetl commonly appeared in the form of a raven, so that the word yetl is used for any raven. So far there seems an arguable case for the mythic raven-deity, on the supposition of Yètl being an expansion of the raven totem. But Professor Boas, after careful examination, does not identify the raven of the legends with the raven of the totem. ${ }^{1}$ It is to be added that the other legendary god Kanuk does not appear as a wolf, nor is a wolf called by his name.

What I venture to protest against is the manner in which totems have been placed almost at the foundation of religion. Totemism, taken up as it was as a side-issue ont of the history of law, and considered with insufficient reference to the immense framework of early religion, has been exaggerated out of proportion to its real theological magnitude. The importance belonging to totemanimals as friends or enemies of man is insignificant in comparison with that of ghosts or clemons, to say nothing of higher deities. The rise and growth of ideas of deity, a branch of knowledge requiring the largest range of information and the greatest care in inference, cannot, I hold, be judged on the basis of a section of theology of secondary importance, namely, animal-worship, much less of a special section of that, namely, the association of a species of animals with a clan of men which results in totemism. A theoretical structure has been raised quite too wide and high for such a foundation.

Some passages may be cited from a recent work of much argumentative alility, the Introduction to the History of Religion, by Dr. F. B. Jevons, in order to show the theological results which may be drawn from the totemistic thenries here discussed, when accepted as established principles and pressed by too confident logic to further consequences. "The sacrifices offered to Jehovah point back, then, not to polytheism, but to a low form of monotheism, in which each clan that offered sacrifice worshipped but one god, though that god was

1 F. Boas in Report of British Association, 1888-9, Committee on N.W. Tribes of Canada; for further details see the previous paper on the "Totem-Post at Fox Warren," p. 133. 
conceiver in the form of the animal or plant which was sacrificed" (p. 392). "The earliest form of society, the clan, is not only a social community, it is also a religious society; fellow-tribesman and fellow-worehipper are convertible terms, because the members of the clan are united to one another, not only by the bond of kinship, but also by joint communion in the sacramental sacrifice of the totem-god" (p. 391). Dr. Jevons places himself at a disadvantage by basing his argument on particular views which he describes as "the most recent results of anthropology," instead of taking the safer course of working out the evidence for himself. The totem-god whom he sets over "the lowest form of monotheism" is, I have tried to show, a merely hypothetical being. Nor does the evidence offered to trace his sacramental position as at once god and victim find any conclusive proof in the totem-worship of the low-cultured world. The inmense influence of sacrificial feasts as means of binding societies of worshippers together, and to their common divinity, is indeed undeniable, and to have pressed it on the public mind is one of the great merits of the late Professor W. R. Smith's teaching. ${ }^{1}$ But when it came to his introducing the totem into the doctrine of the slain god, and suggesting with reference to passages in Mr. Frazer's manual, that totem-sacraments are found among rude hunting tribes, he was, I venture to think, no longer on solid ground. That a Californian tribe should for their amuual festival have killed in each village one of the sacred turkey-buzzards, taking its feathers for the priest to dress in the character of their god who had appeared to the people in such guise, is a rite which explains itself without supposing that the bird was a totem, or its death an expiatory sacrifice. Nor does there seem a piacular notive in the annual rite among the Zuñi Indians of killing the turtles, their kinsfolk, to go to "our lost others" in the lake of the clead. Indeed Mr. Frazer has since changed his opinion of this ceremonial rite, taking it as a case of transmigration of souls. I need not go into further details, preferring to quote a later remark by Mr. Lang, "But Mr. Frazer and I both admit, and indeed are eager to state publicly, that the evidence for sacrifice of the totem and communiou in eating him is very scanty." It may be reasonable to go a step further and suggest that till the totem-sacrament is vouched for by some nore real proof, it had better fall out of speculative theology.

While as yet the time has not come to offer so conclusive an explanation of the origin and development of totemism as would clear the whole subject, it will be well to draw attention to its history of late years. McLennan did not commit himself to a definite theory, which was wise considering the scantiness of the evidence. Mr. Herbert Spencer's conjecture as to ancestors named Wolf, Bear, etc., giving descent to clans so called, is merely artificial. Mr. Frazer in his Totemism leaves the question open, but in his Golden Bough he proposes a theory

1 W. R. Smith in Encyc. Brit., 1886, art. "Sacrifice"; Religion of the Semites, p. 386 ; J. G. Frazer, Totemism, p. 48; Golden Bough, vol. ii, p. 94 ; A. Lang, Modern Mytlcology, 1897.

New Series, Vol. I., Nos. 1 and 2. 
which is to be found in the writings of Professor ( $\mathrm{t}$. A. Wilken, as to the notion of the human soul passing into an animal, plant, or other object, and thus causing a sympathetic connexion between the person and the receptacle of his soul. This Wilken ${ }^{1}$ exemplifies from folklore by the Hindu tale of Punchkin, whose life was bound up with the life of the little green parrot, which was in the little cage, which was under the six water-jars, and so forth ; the Russian tale of Koshchi the deathless, whose death was in an egg, and the egg in a duck; the Malay tale of Bidasari, whose soul was in a fish, etc. Thence we pass to the practice of sorcerers in the Malay archipelago of depositing the souls of people for security outside them at dangerous times, as when the soul of a woman in childbirth is transferred to an iron cleaver in charge of the sorcerer. In this way Wilken accounts for the Mexican idea of the animal assigned to a child as its nagual or tutelary genius, there being lienceforth sympathy between the two, so that the death of the one involves the death of the other. So he explains the sympathetic tree on which the life of a person or family depends, as so often is related in European folklore. This evidence and argument provide Mr. Frazer with a theory of the origin of totems. He argues that the man's relation to the totem is derived from his soul (or one of his souls) residing for security in one of the totem-creatures, whence his worship of them and his objection to killing and eating them, aud their reciprocal kindness to and protection of him, and the general conception that the man and his totem guardian are kinsfolk by descent. It will be seen that this theory goes part of the way toward accounting for the peculiar qualities of totems. But there are also objections to it which seem, to me at least, insuperable. One is that if tribes living under the totem-system really thought their souls were in the totem-animals, we should have heard of it long before this, whereas there does not appear to be a single mention of such an idea. Also the rule that an exogamous savage under the maternal system abstains from killing or eating his totem-animal for fear of losing his life, while his wife and children, being of a different totem, put him daily in such danger by devouring it, seems a hopeless inconsistency. I will not, however, pursue this line of criticism, being more anxious to call attention to Wilken's own view of the origin of totems, which, if it does not completely solve the totemproblem, at any rate seems to mark out its main lines.

This eminent anthropologist has collecter in his Animism among the Peoples of the Malry Archipelago, ${ }^{2}$ accounts of the native animal-worship prevailing in that region, one of those where it is still possible to study the state of mind of peoples who frankly recognise in certain animals their spiritual equals and indeed, stiperiors; beings whose bodies not only have limbs and organs corresponding to their own, but who have, as it were, human thought and speech, and may excel man not merely in strength but in wisdom. The crocodile is especially venerated; he is Tuwan-besar,

1 G. A. Wilken, De Simsonsage ; De Betrekking tusschen Henschen-Dueren-en Plantenlenen ; in Indische Gids, 1884, 1888 : Leber das IIaaropfer, etc., in Revue Coloniale Internationale, 1886-7. pp. $74-5$.

2 G. A. Wilken, Het Animisme bij de Tolken van den Indischen Archipel., 1884-5, part I., 
Great Lord, and regarded as equal in rank to the Dutch Resident. Crocodiles are kindly and protective beings, to kill whom is inurder, indeed they may be man's near relatives; offerings are made to them, and people look forward to the great blesseduess of becoming crocodiles when they die. So it is with tigers, whom the Sumatrans worship and call ancestors (nenek), whom their countrymen will not catch or wound but in self-defence, so that when one has been trapped they try to persuade him that it was not their doing. Wilken sees in this transmigration of souls the link which connects totemism with ancestor-worship, and on considering his suggestion, we may see how much weight is to be given to the remarks made independently by I)r. Codrington ${ }^{1}$ as to Melanesia. He found that the people in Ulawa would not eat or plant bananas, because an influential man had prohibited the eating of the banana after his death because he would be in it; the elder natives would say, we camnot eat so-and-so, and after a few years they would have said, we cannot eat our ancestor. In Malanta, a man will often say he will be in a shark. Ir. Codrington has lately sent me a note from Mr. Sleigh, of Lifu, who writes: "When a father was about to die, surrounded by members of his family, he might say what animal he will be, say a butterfly or some kind of bircl. That creature would be sacred to his family, who would not injure or kill it; on seeing or falling in with such an object the person would say, 'That is kaka (papa),' and would, if possible, offer him a young cocoa-nut. But they did not adopt thus the name of a tribe." As to such details, we may, I think, accept the cautious remark of Dr. Codrington, that in the Solomon Islands there are incleed no totems, but what throws light on them elsewhere. The difficulty in understanding the relation of a clan of men to a species of animals or plants is met by the transmigration of souls, which bridges over the gap between the two, so that the men and the animals become united by kinship and mutual alliance; an ancestor having lineal descendants among men and sharks, or men and owls, is thus the founder of a totemfamily, which mere increase may convert into a totem-clan, alreacly provided with its animal name. By thus finding in the world-wide doctrine of soul-transference an actual cause producing the two collateral lines of man and beast which constitute the necessary framework of totemism, we seem to reach at least something analogous to its real cause. But considering the variations found even between neighbouring tribes in the working of their ideas, it would be incautious to lay down as yet a hard and fast scheme of their origin and development. As an example of this may be taken the remarkable new information by Professor Baldwin Spencer, ${ }^{2}$ of Melbourne, as to the totem-system of the Arunta tribe, contained in papers communicated to the Royal Society of Victoria in anticipation of his forthcoming work on the Tribes of Central Australia. The exogamous arrangements of the Aruntas, as is common in the country, depend on classes or phratries, descent being on the father's side. Individuals are classed by totem-names, Hawk, Witchetty Grub, Emu, Kanguru, Grass Seed, etc., though these do not

1 R. H. Codrington, The Melanesians, pp. 32-3.

2 W. B. Spencer in Proc. Roy. Soc. Irictoria, vol. x, N.S., 1897-8. 
regulate the marriages. The explorers were much perplexed to find that such totem-names of the children did not necessarily follow those of either parent; thus of two parents, both Witchetty Grubs, one child might have the same totem and another be a Wild Cat. On inquiry into this apparent confusion, a mythical meaning was disclosed by the natives somewhat as follows: In the old alcheringa or dream times, it was explained there were ancestors who lived and wandered aloout the land in groups of kangaroo-men and emu-men and the like, of whom one could not say whether they were men, or kangaroos and emus. That these names representerl totems seems clear from the belief that at first each group belongerl to its proper half of the trilie. As these ancestors wanclererl over the land, some of them went into the ground at certain spots and turnerl into the sacred churingas or bull-rcarers so important in native Australian rites, and thus in the Arunta country there are numerous spots where these wooden lummming instruments are buried, each associated with a spirit-ancestor, and carrying his or her totem-name. As the natives now wander about the country, wherever a child is conceived, one of the ancestor-spirits deposited in that place enters into that child, who takes the local totem accordingly, becoming a Bandicoot or a Witchetty ( $\mathrm{rrub}$, or what not. A more extraordinary animistic scheme was perhaps never known, yet even here the transference of souls between the man-line and the beast-line is evident.

In these remarks it has seemed safest not to pursue analogies, developments, or survivals of totemism into the religions of the old civilised world, Egypt, Pabylonia, India. It may be best to postpone such inquiries until savage and barbaric animal-worship has been more strictly classified, and the totem has shrunk to the dimensions it is justly entitled to in the theological schemes of the world. Nor do I propose to enter into detailed discussion of the social results on the strength of which totemism claims a far greater importance in sociology than in religion, connected as it is with the alliance between clans which ensues from the law of exogamy only allowing marriage between different clans, as determined by the clan totems. Exogamy can and does exist without totemism, and for all we know was originally independent of it, but the frequency of their close combination over three-quarters of the earth points to the ancient and powerful action of the totems at once in consolidating clans and allying them together within the larger circle of the tribe. This may well have been among the most effective processes in the early social growth of the human race. 